\title{
MIKROENKAPSULASI PIGMEN DARI KUBIS MERAH: STUDI INTENSITAS WARNA DAN AKTIVITAS ANTIOKSIDAN
}

\author{
[Microencapsulation of Pigments from Red Cabbage: \\ Color Strength and Antioxidant Activity]
}

\author{
Diah Mustika Lukitasari ${ }^{1)}$, Renny Indrawati ${ }^{1,2) \star}$, Rosita Dwi Chandra ${ }^{1)}$, Heriyanto ${ }^{1,2)}$, dan \\ Leenawaty Limantara ${ }^{1,3)}$ \\ 1) Ma Chung Research Center for Photosynthetic Pigments (MRCPP), Universitas Ma Chung, Malang \\ 2) Jurusan Kimia, Fakultas IImu Pengetahuan dan Teknologi, Universitas Ma Chung, Malang \\ 3) Center for Urban Studies, Universitas Pembangunan Jaya, Tangerang
}

Diterima 21 November 2016 / Disetujui 27 April 2017

\begin{abstract}
Utilization of artificial food colorants has obtained particular concem for long time consumption. Red cabbage (Brassica oleracea L. var. capitata forma rubra L.) was extracted to produce a candidate for natural food colorant through a one-step physical extraction and microencapsulation. The color strength was determined by measuring: (1) tinctorial strength, (2) color degradation kinetics at various $\mathrm{pH}$, and (3) thermostability. Yield level and antioxidant activity were enclosed as supporting data. The results showed that extract of red cabbage exhibited vivid red until green color at various $\mathrm{pH}$ and was nearly stable at $\mathrm{pH} 2$

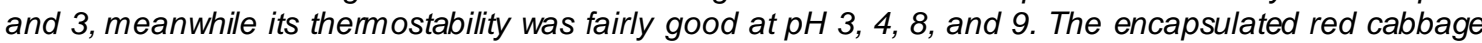
extract produced high color intensity at $\mathrm{pH} 2$ for red color and $\mathrm{pH} 9$ for blue color with a yield level of $5.53 \%$. It also showed antioxidant activity with $I C_{50}$ value of $725.65 \pm 0.086 \mathrm{ppm}$ in methanol solvent and 258.25 $\pm 0.097 \mathrm{ppm}$ in water-methanol solvent.
\end{abstract}

Keywords: antioxidant activity, food colorants, red cabbage, stability, tinctorial strength

\section{ABSTRAK}

Penggunaan pewama sintetis pada makanan telah mendapat perhatian serius, terutama terkait efek samping jika dikonsumsi dalam jangka waktu yang lama. Kubis merah (Brassica oleracea L. var. capitata forma rubra L.) berpotensi untuk diekstrak menjadi pewarna alami pangan melalui ekstraksi secara fisik dan dilanjutkan dengan mikroenkapsulasi. Adapun parameter yang diuji dalam penelitian ini yakni intensitas wama, degradasi warna terhadap variasi pH selama kurun waktu tertentu, dan degradasi warna terhadap perlakuan panas. Kadar rendemen dan aktivitas antioksidan merupakan data penunjang dari penelitian ini. Hasil penelitian menunjukkan bahwa enkapsulat pigmen kubis merah memberikan warna merah cerah hingga hijau pada beragam $\mathrm{pH}$, dan cukup stabil pada $\mathrm{pH} 2$ dan 3 , sedangkan pengujian termostabilitas menunjukkan bahwa pigmen kubis merah cukup stabil pada $\mathrm{pH} 3,4,8$, dan 9 . Enkapsulat pigmen kubis merah menunjukkan intensitas warna tertinggi pada $\mathrm{pH} 2(2687,5 \pm 0,01 \%)$ untuk warna merah dan $\mathrm{pH} 9(2168,9 \pm 0,004 \%)$ untuk warna biru dengan rendemen 5,53\%. Enkapsulat pigmen kubis merah menunjukkan aktivitas antioksidan dengan nilai $I_{50} 725,65 \pm 0,09$ ppm dalam pelanut metanol dan $258,25 \pm 0,10 \mathrm{ppm}$ dalam pelarut air-metanol.

Kata kunci: aktivitas antioksidan, intensitas warna, kubis merah, pewarna makanan, stabilitas

\section{PENDAHULUAN}

Kubis merah merupakan sejenis sayuran pelengkap salad yang dapat memenuhi $61 \%$ kebutuhan vitamin $\mathrm{K}$ per hari, tinggi akan serat, dan mengandung gula alami yang dapat memberikan efek kesehatan bagi manusia (Dragichi et al., 2013). Kubis merah mengandung vitamin $\mathrm{A}, \mathrm{B}, \mathrm{C}$, dan $\mathrm{E}$,

${ }^{*}$ Penulis Korespondensi:

E-mail: renny.indrawati@machung.ac.id kalsium, kalium, fosfor, natrium, besi, sulfofaran, dan antosianin (Neelufar et al., 2012). Antosianin yang terkandung dalam kubis merah berpotensi sebagai pewarna alami merah pada bahan pangan yang memiliki sisi positif sebagai antioksidan terhadap radikal bebas (Senja et al., 2014). Antosianin merupakan pigmen yang tersusun dari flavonoid (antosianidin) dengan cincin aromatik pada cincin B, cincin siklik C6-C3-C6, dan gugus gula dengan posisi yang berbeda. Antosianin merupakan pigmen larut air yang terdapat di sel epidermis pada bunga 
atau di sel mesofil pada daun. Jenis antosianin yang terkandung dalam kubis merah yakni cyanidins dengan gugus gula baik yang terasilasi dengan kafeat, ferulat, asam sinapat, dan p-koumarat maupun tidak (Hong dan Meng, 2015).

Kubis merah mengandung antosianin yang menimbulkan perubahan warna pada suasana asam maupun basa bergantung pada jenis ikatan quinoidal, flavilium, chalcone, dan pseudobase (Lopes et al., 2011). Antosianin dapat menjadi salah satu alternatif pewarna alami dalam bahan pangan dan obat-obatan (He et al., 2010). Pewarna alami umumnya memiliki sifat tidak stabil terhadap $\mathrm{pH}$, panas, maupun cahaya bergantung dari jenis pigmen dan sumbernya, sehingga dapat dibedakan dengan mudah dari pewarna sintetis. Xavier et al. (2008) menyatakan ekstraksi kubis merah dengan menggunakan larutan asam asetat $(5,10$, dan $20 \%$ v/v) menunjukkan konsentrasi warna yang lebih tinggi dibandingkan dengan menggunakan buffer Mclllvaine ( $\mathrm{pH} \mathrm{3,} \mathrm{4,} \mathrm{dan} \mathrm{5)} \mathrm{dan} \mathrm{metanol} \mathrm{(30,} \mathrm{40,} \mathrm{dan}$ $70 \% \mathrm{v} / \mathrm{v})$. Chandrasekhar et al. (2012) menyatakan pula ekstraksi menggunakan acidified ethanol (50\%, v/v) menunjukkan kandungan antosianin tertinggi dibandingkan menggunakan pelarut air, acidified water, metanol, acidified methanol, dan aseton. Ekstraksi kubis merah menggunakan pelarut organik memiliki warna pekat namun menimbulkan residu kimia $(\mathrm{HCl})$ seperti yang dinyatakan oleh Gomathi et al. (2013) saat melakukan ekstraksi kubis merah menggunakan acidified methanol. Berdasarkan pertimbangan adanya resiko terdapat residu bahan kimia, maka perlu dikaji cara ekstraksi untuk mendapatkan ekstrak pekat antosianin tanpa menggunakan pelarut organik. Salah satu metode yang dapat digunakan adalah ekstraksi fisik, yakni menggunakan air bebas dari kubis merah.

Tujuan umum penelitian ini yakni mendapatkan informasi tentang intensitas warna dan aktivitas antioksidan dari enkapsulat pigmen kubis merah. Adapun tujuan khusus dari penelitian ini yakni mendapatkan informasi mengenai kestabilan ekstrak kubis merah terhadap variasi $\mathrm{pH}$ dan panas, sehingga dapat menjadi referensi apabila enkapsulat pigmen diaplikasikan dalam produk pangan.

\section{BAHAN DAN METODE}

\section{Bahan}

Bahan yang digunakan dalam penelitian adalah kubis merah segar yang diperoleh dari Lai-Lai Market Buah. Maltodekstrin (MD) (Yishui Dadi Corn Developing Co., Ltd., China) dengan DE 10-12\%.

\section{Preparasi sampel}

Kubis merah segar disortasi, dicuci dengan air bersih, ditiriskan kemudian ditimbang menggunakan Electronic Kitchen Scale (Kris Chef-EK9350H).
Kubis merah kemudian dipotong menggunakan pisau stainless steel (Kris Chef) menjadi beberapa bagian yang lebih kecil kemudian diekstrak menggunakan slow juicer HH-SBF11 (Hurom, USA, Inc.) tanpa penambahan air. Ekstrak yang diperoleh kemudian ditambahkan maltodekstrin sebanyak 5\% (b/v) dan dibekukan semalam menggunakan freezer (Polytron, PT Sarana Kencana Mulya Kudus).

\section{Kondisi pengeringan}

Ekstrak yang telah dibekukan dalam freezer kemudian didinginkan dengan metode freeze drying (Labconco-FreeZone $2.5 \mathrm{~L}$ Benchtop) selama 48 jam dengan suhu $-49^{\circ} \mathrm{C}$ dan tekanan 0,04 MPa. Enkapsulat pigmen kubis merah yang telah dikeringkan kemudian ditumbuk, dimasukkan ke dalam wadah plastik, kemudian di-bubbling dengan gas $\mathrm{N}_{2}$ (PT. Samator Gas Industri, Indonesia).

\section{Rendemen dan kadar air (moisture analyzer)}

Prosedur pengujian rendemen adalah dengan menimbang sampel yang telah dicuci, kemudian menimbang berat ekstrak yang telah dikeringkan dengan metode freeze drying menggunakan timbangan analitik Sartorius BT224S (Osaka, Japan). Untuk menentukan kadar air, sampel ditimbang dan diukur dengan menggunakan Moisture Tester Shimadzu-MOC63U (Kyoto, Japan). Persentase kadar air dan rendemen terhitung dengan menggunakan rumus:

$$
\%=\frac{\text { berat basah-berat kering }}{\text { berat basah }} \times 100
$$

\section{Preparasi buffer Mclllvaine (Modifikasi Molina et al., 2014)}

Pembuatan buffer Mclllvaine mengacu pada Molina et al. (2014) dengan sedikit modifikasi pada proporsi asam sitrat dan $\mathrm{Na}_{2} \mathrm{HPO}_{4}$. Adapun pembuatan buffer Mclllvaine yakni dengan melarutkan $<2 \%$ asam sitrat (Lianyungang Chameleon Technology Co. Ltd, China), <2\% $\mathrm{Na}_{2} \mathrm{HPO}_{4}$ (Lianyungang Chameleon Technology Co. Ltd, China), dan 0,02\% sodium asida (Amresco Inc, USA) dalam akuades (Panadia Laboratory, Indonesia) yang telah disaring menggunakan water purifier (Thermo Scientific 7133-USA Ltd).

\section{Analisis intensitas warna (Reyes dan Zevallos, 2007)}

Enkapsulat pigmen kubis merah dilarutkan ke dalam akuades dengan konsentrasi $0,1 \%$ (b/v), dihomogenisasi menggunakan magnetic stirrer VELP SCIENTIFICA AMI4 (Leicestershire, England), kemudian dilakukan pengukuran dengan spektrofotometer Shimadzu UV-1800 (Kyoto, Japan) pada panjang gelombang 200-900 nm dan ColorFlex EZ Hunter Associates Laboratory Inc. (Reston, USA) 
pada panjang gelombang 400-700 nm. Persentase nilai intensitas warna dan nilai chroma terhitung dengan menggunakan rumus:

Intensitas Warna $=\frac{\text { absorbansi maksimum }}{\text { berat sampel }} \times 100$.

Chroma $=\sqrt{a^{* 2}+b^{* 2}}$

\section{Evaluasi stabilitas pigmen (Modifika si Reyes dan Zevallos, 2007)}

Stabilitas enkapsulat pigmen kubis merah ditentukan dengan menggunakan modifikasi metode Reyes dan Zevallos (2007) pada penggunaan buffer Mclllvaine, volume ekstrak, konsentrasi ekstrak, suhu penyimpanan, waktu penyimpanan dan variasi $\mathrm{pH}$ yang diuji. Ekstrak kubis merah konsentrasi 0,1\% (b/v) dilarutkan pada buffer Mclllvaine dengan rentang $\mathrm{pH}$ 2-11, kemudian disimpan pada climate chamber Memmert ICH110 (Schwabach, Germany) dengan suhu $20^{\circ} \mathrm{C}, \mathrm{RH} 15,1 \%$ dalam kondisi gelap. Sampel diamati pada jam ke 0, 6, 12, 24, 48 dan 72 menggunakan ColorFlex dengan panjang gelombang $400-700 \mathrm{~nm}$. Persentase nilai degradasi derajat warna dihitung menggunakan rumus:

$\%$ Degradasi $=$

$\frac{\text { (nilai derajat warna awal-nilai derajat wama akhir) }}{\text { nilai }} \times 100$

Identifikasi adanya perubahan pada derajat warna ditentukan dengan menghitung nilai $\Delta E$ menggunakan rumus [5]. Adapun warna standar untuk menghitung nilai $\Delta$ berdasarkan warna enkapsulat pigmen kubis merah awal setelah dilarutkan dalam buffer Mclllvaine sebelum mengalami masa penyimpanan.

$$
\Delta \mathrm{E}=\sqrt{\left(\Delta \mathrm{L}^{* 2}\right)+\left(\Delta \mathrm{a}^{* 2}\right)+\left(\Delta \mathrm{b}^{* 2}\right)}
$$

\section{Evaluasi thermostabilitas pigmen (Modifikasi Reyes dan Zevallos, 2007)}

Thermostabilitas enkapsulat pigmen kubis merah ditentukan dengan menggunakan modifikasi metode Reyes dan Zevallos (2007) pada penggunaan buffer Mclllvaine, volume ekstrak, konsentrasi ekstrak, suhu penyimpanan, waktu penyimpanan dan variasi $\mathrm{pH}$ yang diuji. Ekstrak kubis merah konsentrasi $0,1 \% \quad(\mathrm{~b} / \mathrm{v})$ dilarutkan dalam buffer Mclllvaine dengan rentang $\mathrm{pH} 2-11$. Ekstrak yang telah dihomogenisasi menggunakan magnetic stirrer ke-mudian diinkubasi pada suhu $60^{\circ} \mathrm{C}$ selama 30 menit. Pengujian dilakukan menggunakan ColorFlex EZ dengan panjang gelombang 400-700 nm setelah ekstrak mendingin. Rumus persentase degradasi dapat dilihat pada subbab analisis stabilitas warna [4].

\section{Evaluasi aktivitas antioksidan dan IC $_{50}$ (Modifi- kasi Dehbi et al., 2012)}

Aktivitas antioksidan dan $\mathrm{IC}_{50}$ pada enkapsulat pigmen kubis merah ditentukan dengan menggunakan modifikasi metode Dehbi et al. (2012) pada konsentrasi DPPH yang digunakan, volume sampel dan volume DPPH yang digunakan. Enkapsulat pigmen kubis merah dilarutkan dalam air hingga konsentrasi 1000 ppm, kemudian dilakukan seri pengenceran dengan menggunakan metanol (Merck Co \& Inc, USA), diikuti dengan penambahan larutan DPPH 0,2 $\mu \mathrm{M}$ (Sigma Aldrich, Germany Ltd.). Sampel diinkubasi selama 30 menit, kemudian ditera pada panjang gelombang $517 \mathrm{~nm}$. Persentase aktivitas antioksidan dan nilai $\mathrm{IC}_{50}$ dihitung menggunakan rumus:

Aktivitas Antioksidan $=$

$\underline{\text { blanko-absorbansi sampel }} \times 100 \%$

Untuk memperoleh nilai $\mathrm{IC}_{50}$ melalui rumus $[\mathrm{y}=\mathrm{ax}+$ b] dari \% aktivitas antioksidan

Nilai a dan b merupakan konstanta yang didapatkan dari persamaan garis lurus aktivitas antioksidan.

\section{Analisa data}

Data pengujian dianalisis secara statistik dengan menghitung nilai rata-rata dan standart error (SE) dengan Microsoft Office Excel 2013. Semua data yang diperoleh dalam bentuk nilai rerata dari pengujian duplo \pm standart error.

\section{HASIL DAN PEMBAHASAN}

\section{Kadar air}

Kadar air yang terkandung dalam kubis merah segar sebesar $89,62 \pm 0,34 \%$, sedangkan kadar air enkapsulat pigmen kubis merah yang telah dikeringkan sebesar 12,57 $\pm 1,84 \%$. Asgar dan Musaddad, (2006) menyatakan kubis kering memiliki rentang kadar air berkisar antara 7,7-9,23\%. Adapun faktorfaktor yang memengaruhi sifat higroskopis bahan yakni jenis bahan baku, kandungan gula yang terdapat dalam bahan, bahan penyalut, kelembaban udara, metode pengeringan dan penyimpanan. Enkapsulat pigmen kubis merah dikeringkan dengan menggunakan freeze dryer selama 48 jam. Metode ini digunakan untuk menghindari kerusakan pigmen saat menggunakan suhu tinggi, sehingga dapat mempertahankan warna saat diaplikasikan ke dalam bahan pangan. Pengeringan menggunakan freeze dryer dan penyimpanan dalam kondisi dingin dapat meningkatkan kapasitas higroskopis bahan saat akan diukur kadar airnya. Ribeiro et al. (2016) menyatakan kandungan gula dalam buah dan sayur 
memicu tingginya kemampuan higroskopis serbuk karena gula memilki interaksi yang kuat dengan molekul air. Yuliawaty dan Susanto. (2014) menyatakan penambahan maltodektrin dalam produk yang akan dikeringkan akan meningkatkan tingkat readsorpsi air, yang dipicu oleh adanya gugus hidroksil pada maltodektrin.

Kubis merah segar pada berat awal $494 \mathrm{~g}$ dapat menghasilkan rendemen enkapsulat pigmen kubis merah sebesar 27,30 g (5,53\%). Kubis merah diekstrak secara fisik dan tanpa penambahan air sehingga diperoleh ekstrak kental dengan kandungan air dari bahan. Ekstraksi tanpa penambahan air memiliki kelebihan yakni konsentrasi ekstrak yang lebih tinggi dan tidak ada residu pelarut organik, namun ekstraksi dengan metode ini juga memiliki kelemahan yakni rendemen yang dihasilkan lebih rendah dibandingkan ekstraksi yang menggunakan pelarut. Jumlah rendemen ekstraksi tanpa penambahan air sangat bergantung pada jumlah air bebas yang terdapat pada bahan, sebab pigmen yang terdapat pada celah sel dan fraksi air terikat baru dapat dibebaskan dengan metode kimiawi. Senja et al. (2014) menunjukkan kubis merah yang dimaserasi dengan etanol $96 \%$ kemudian dikeringkan dengan freeze drying memiliki rendemen sebesar $37,11 \%$. Jenis pelarut, metode ekstraksi, suhu ekstraksi, kandungan bahan, dan tingkat kematangan bahan memengaruhi kadar rendemen ekstrak berdasarkan komponen dan senyawa fitokimia yang mampu terekstrak dari bahan baku selama proses ekstraksi (Senja et al., 2014).

\section{Kenampakan warna ekstrak kubis merah ter- hadap variasi $\mathrm{pH}$}

Pemberian buffer Mclllvaine dengan rentang $\mathrm{pH}$ 2-11 terhadap enkapsulat pigmen kubis merah sebesar 0,1\% menunjukkan perubahan warna yang cukup beragam (Gambar 1).

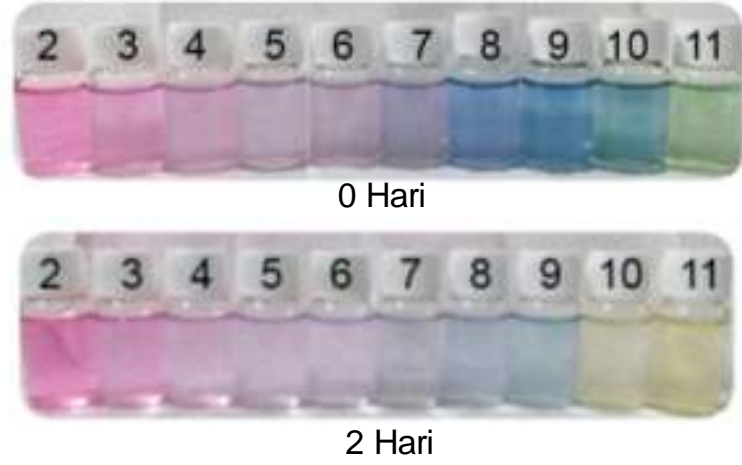

Gambar 1. Kenampakan enkapsulat pigmen kubis merah dalam buffer Mclllvaine $\mathrm{pH}$ 2-11 (konsetrasi $0,1 \%$ ) pada penyimpanan suhu $20^{\circ} \mathrm{C}$, kondisi gelap
Enkapsulat pigmen kubis merah memberikan warna merah saat dilarutkan pada $\mathrm{pH} 2-4$, memberikan warna ungu pucat mendekati transparan pada pH 5-7, memberikan warna biru pada pH 8-10, dan memberikan warna hijau $\mathrm{pH} 11$. Kenampakan visual dari Iarutan enkapsulat pigmen kubis merah memudar seiring dengan lamanya waktu penyimpanan. Pada Gambar 2 menunjukkan nilai chroma pada enkapsulat pigmen kubis merah. Pada $\mathrm{pH}$ rendah menunjukkan intensitas warna tertinggi, intensitas menurun saat mendekati $\mathrm{pH}$ netral, kemudian kembali meningkat saat diberi $\mathrm{pH}$ basa. Kenampakan secara visual dari enkapsulat pigmen kubis merah sesuai dengan pernyataan Tanaka et al. (2008) dimana antosianin akan berwarna merah pada $\mathrm{pH}$ rendah $(\mathrm{pH}<3)$, berwarna pudar hingga transparan pada $\mathrm{pH} 3-6$, serta berwarna biru pada $\mathrm{pH}$ basa $(\mathrm{pH}>6)$. Antosianin stabil pada $\mathrm{pH}$ rendah dalam bentuk kation flavilium, namun sangat tidak stabil pada $\mathrm{pH}$ basa (dalam bentuk quinonoidal) (Vargas dan Lopez, 2003). Reyes dan Zevallos (2007), menyatakan warna sampel dalam buffer pada $\mathrm{pH}$ basa berubah menjadi kuning setelah masa inkubasi selama 2-3 hari pada $\mathrm{pH} 3$, dan penyimpanan suhu $25^{\circ} \mathrm{C}$.

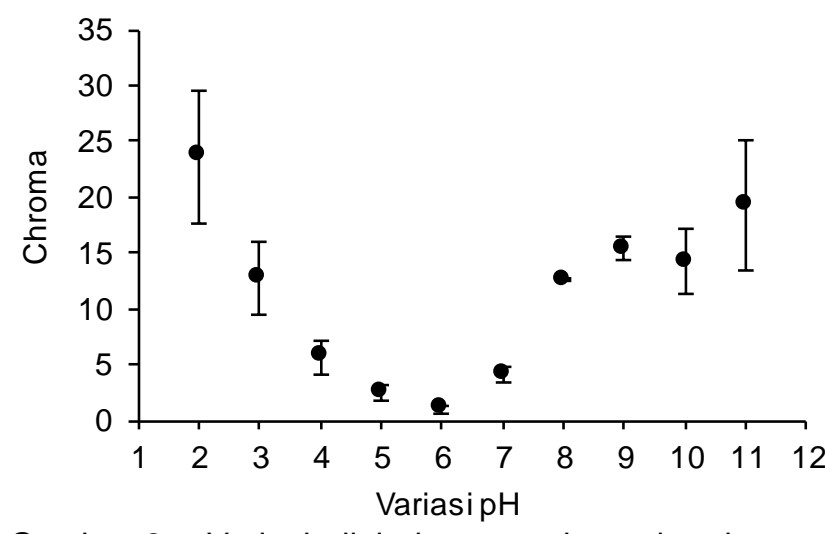

Gambar 2. Variasi nilai chroma enkapsulat pigmen kubis merah dalam buffer Mclllvaine ph 2-11 (konsentrasi 0,01\%) pada penyimpanan suhu $20^{\circ} \mathrm{C}$ kondisi gelap

\section{Intensitas warna}

Intensitas warna menunjukkan kekuatan warna saat warna yang terdapat dalam ekstrak diaplikasikan dalam produk. Variasi warna yang timbul saat enkapsulat pigmen kubis merah dilarutkan dalam buffer Mclllvaine dengan rentang $\mathrm{pH}$ 2-11 juga menunjukkan perbedaan intensitas (Gambar 3). Enkapsulat pigmen kubis merah memiliki intensitas warna tertinggi pada kondisi asam dan basa yakni $\mathrm{pH} 2(2687,5 \pm 0,01 \%)$ dengan warna merah cerah dan $\mathrm{pH} 9(2168,9 \pm 0,004 \%)$ dengan warna biru cerah. Pada $\mathrm{pH} 10$ juga menunjukkan warna biru namun tidak sekuat $\mathrm{pH}$, intensitas warna pada $\mathrm{pH}$ 10 hanya mencapai $2152,8 \pm 0,004 \%$. Intensitas warna terendah terdapat pada $\mathrm{pH} 11$ dengan per- 
sentase intensitas warna sebesar $278,94 \pm 0,004 \%$. Perubahan warna pigmen antosianin pada kubis merah bergantung pada proporsi dan konsentrasi dari kation flavilium dan basa quinoidal hingga mencapai equilibrium (Xavier et al., 2008).

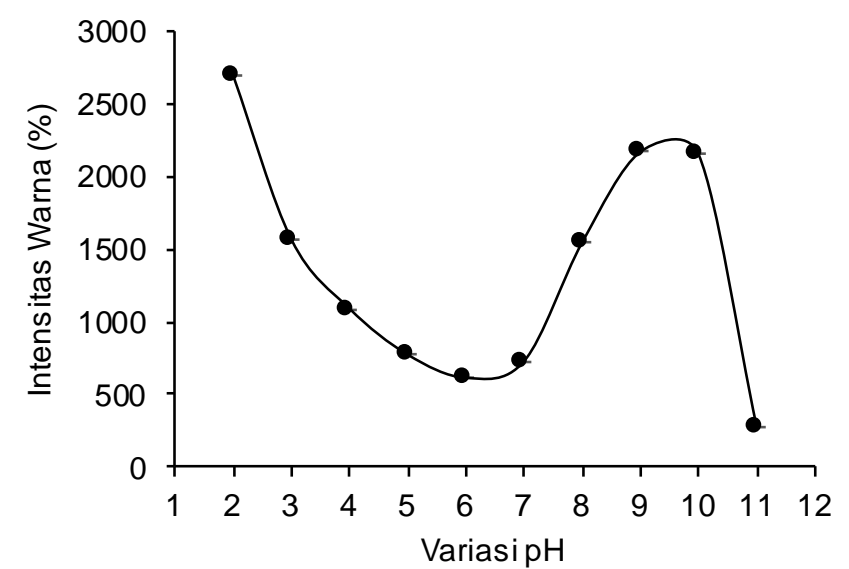

Gambar 3. Intensitas warna pada enkapsulat pigmen kubis merah

\section{Stabilitas warna}

Persentase degradasi nilai $L^{*}$ menunjukkan yang relatif stabil pada $\mathrm{pH}$ 2-6 dengan rentang degradasi nilai $L^{*}$ sebesar $(-0,3)-0,6 \%$; sedangkan pada $\mathrm{pH}$ 7-10 cenderung mengalami peningkatan warna dengan rentang $0,4-6,7 \%$. Nilai negatif pada prosentase degradasi nilai $L^{*}$ menunjukkan enkapsulat pigmen kubis merah mengalami peningkatan warna menjadi lebih transparan dibandingkan dengan warna awal dari ekstrak tersebut. Bernstein dan Noreňa (2015) menyatakan penambahan bahan mikroenkapsulasi seperti gum arab dan polidektrosa mampu menghambat reaksi maillard selama masa penyimpanan dan meningkatkan nilai $L$ (tingkat kecerahan) melalui tampilan putih melalui dinding material dari sampel. Kestabilan enkapsulat pigmen kubis merah pada $\mathrm{pH}$ 2-3 dengan peningkatan derajat warna (nilai $a^{*}$ ) sebesar $2,7-7,4 \%$ setelah penyimpanan selama 72 jam. Pada pH 5 mengalami sedikit peningkatan degradasi nilai $a^{*}$ terutama pada jam ke-48 sebesar $32,3 \%$, sedangkan pada $\mathrm{pH}$ basa (pH 8-11) menunjukkan pola yang sama pada degradasi nilai $\mathrm{a}^{*}$ dengan rentang $4,7-27,7 \%$ pada kondisi awal sebelum penyimpanan menjadi 55,4$73,8 \%$ setelah penyimpanan $72 \mathrm{jam}$. Pada $\mathrm{pH} 6$ dan $\mathrm{pH} 7$ enkapsulat pigmen kubis merah mengalami peningkatan nilai $\mathrm{a}^{*}$ yang ditunjukkan oleh nilai negatif dengan rentang $16-27 \%$ pada kondisi awal sebelum penyimpanan menjadi $50-170 \%$ setelah penyimpanan 72 jam. Ahmadiani et al. (2016) menyatakan degradasi pigmen minimal pada $\mathrm{pH}$ asam yakni $\mathrm{pH} 1$ dan 2, kemudian meningkat hingga diatas $10 \%$ pada $\mathrm{pH} 6$ hingga $\mathrm{pH} 8$. Pada $\mathrm{pH}$ 2, 5, dan 6 menunjukkan peningkatan derajat warna pada nilai $b^{*}$. Pada $\mathrm{pH} 2$ peningkatan cukup signifikan yakni sebesar 1,02\% pada kondisi awal sebelum penyimpanan menjadi $7,12 \%$ setelah penyimpanan 72 jam. Peningkatan ini tidak sebesar $\mathrm{pH} 5$ dan 6 yang memiliki rentang peningkatan derajat warna nilai $b^{*}$ sebesar $39-48 \%$ pada kondisi awal sebelum penyimpanan menjadi $308-499 \%$ setelah penyimpanan 72 jam. Pada pH 8-9 menunjukkan degradasi nilai $b^{*}$ yang cukup signifikan yang ditunjukkan dengan degradasi sebesar $25-29 \%$ pada kondisi awal sebelum penyimpanan dan $122-126 \%$ setelah penyimpanan 72 jam. Data penelitian enkapsulat pigmen kubis merah menunjukkan kesesuaian dengan penelitian Ahmadiani et al. (2014) dimana tingkat degradasi antosianin dalam $\mathrm{pH}$ netral hingga $\mathrm{pH}$ basa mencapai $53 \%$ setelah penyimpanan 6 jam di lemari pendingin.

Perubahan nilai $L^{*}, a^{*}$, dan $b^{*}$ pada suhu $20^{\circ} \mathrm{C}$ selama masa penyimpanan 72 jam dapat ditunjukkan melalui perubahan nilai chroma pada Gambar 4. Nilai chroma pada pH 3-11 enkapsulat pigmen kubis merah cenderung mengalami penurunan, namun pada $\mathrm{pH} 5$ dan $\mathrm{pH} 6$ nilai chroma cenderung lebih stabil yang ditunjukkan dengan nilai chroma 0,2-0,5 pada kondisi awal sebelum penyimpanan dan 0,53,3 setelah penyimpanan selama 72 jam. Pekatnya warna merah pada $\mathrm{pH} 2$ didukung oleh data chroma yang meningkat seiring lama waktu penyimpanan. Pada kondisi segar nilai chroma pada pH 2 mencapai 19,7 setelah inkubasi $20^{\circ} \mathrm{C}$ selama 72 jam dalam kondisi gelap, nilai chroma enkapsulat pigmen kubis merah mencapai 21,1. Ahmadiani et al. (2014) menyatakan nilai chroma pada $\mathrm{pH}$ asam cenderung lebih tinggi dengan menampilkan warna merah mudah pekat dan ${ }^{\circ}$ hue mendekati $350^{\circ}$. Nilai chroma pada $\mathrm{pH} 11$ cukup tinggi dibandingkan nilai chroma pada enkapsulat pigmen kubis merah dalam $\mathrm{pH}$ basa yang lain. Pada $\mathrm{pH} 11$, nilai chroma pada kondisi awal sebelum penyimpanan sebesar 16,3 kemudian menurun menjadi 10,4 setelah penyimpanan selama 72 jam. Perubahan $\Delta E$ pada $\mathrm{pH} 2-6$ sangat kecil, pada jam ke 6 rentang perubahan $\Delta E$ berkisar antara 0,06-0,58 serta perubahan $\Delta E \mathrm{pH}$ 26 setelah 72 jam hanya berkisar 0,34-3,87 (Gambar 5). Habekost (2013) menyatakan jika nilai $\Delta E<1$, perubahan warna tidak dapat dilihat langsung oleh mata, pada nilai $\Delta E$ 1-2 perubahan warna akan terlihat oleh mata yang terlatih, sedangkan nilai $\Delta E$ 23,5 atau diatasnya, maka perubahan warna dapat dilihat oleh mata tidak terlatih. Perubahan $\triangle E$ terlihat jelas pada $\mathrm{pH}$ 8-11, dengan rentang $\Delta E$ sebesar 26,4 pada jam ke-6 kemudian mengalami peningka$\tan \Delta E$ pada jam ke-72 dengan rentang $\Delta E$ sebesar 6,3-11,4. Meskipun intensitas warna pada $\mathrm{pH}$ basa menunjukkan warna biru dan hijau yang kuat namun intensitas warna pada $\mathrm{pH}$ basa tersebut relatif tidak stabil. 


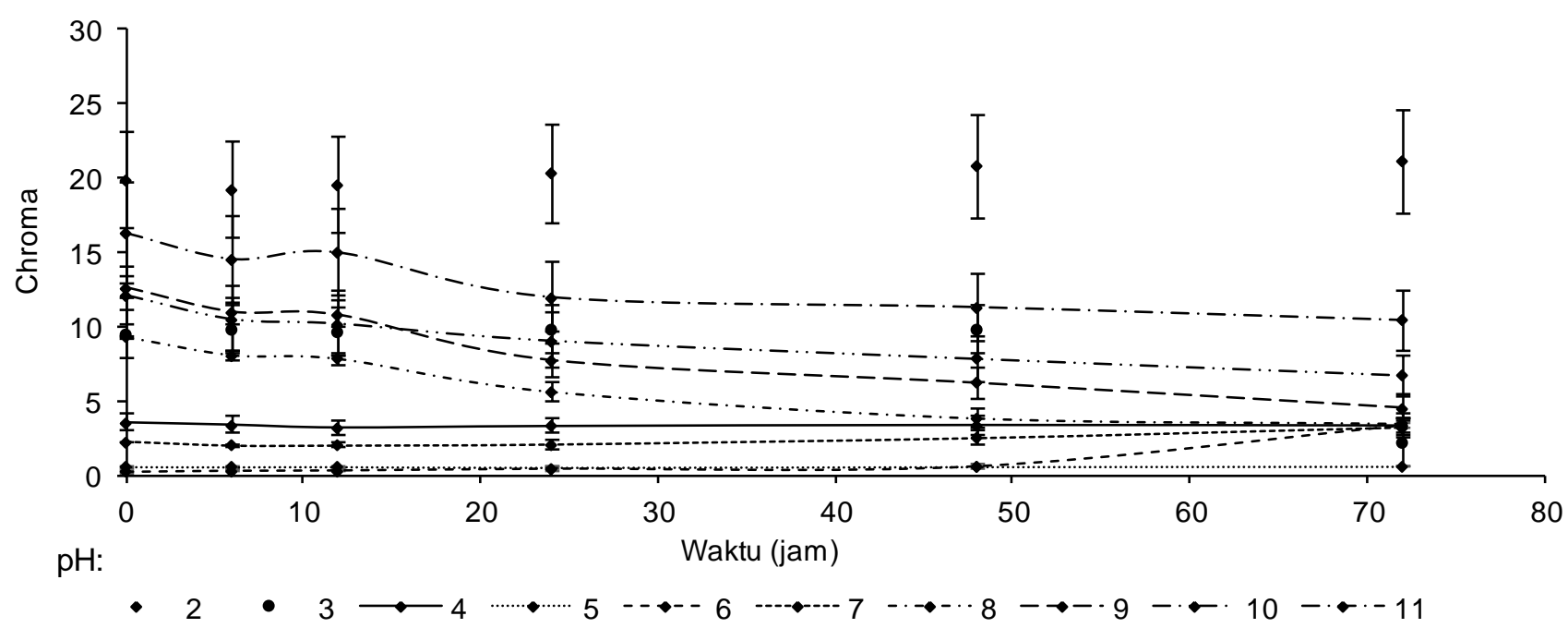

Gambar 4. Perubahan nilai chroma enkapsulat pigmen kubis merah pada penyimpa-nan selama 72 jam, suhu $20^{\circ} \mathrm{C}$, dalam buffer Mclllvaine $(\mathrm{pH} 2-11)$

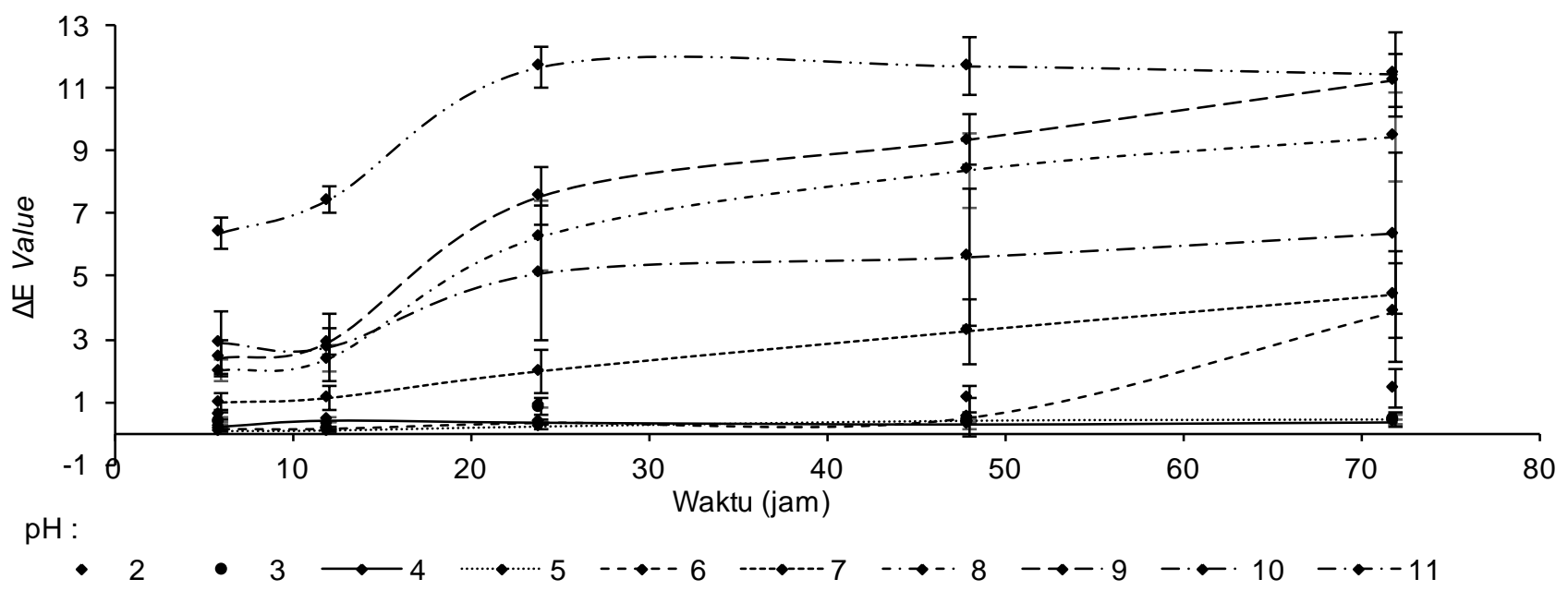

Gambar 5. Perubahan nilai $\Delta E$ enkapsulat pigmen kubis merah pada penyimpanan selama 72 jam, suhu $20^{\circ} \mathrm{C}$, dalam buffer Mclllvaine $(\mathrm{pH} 2-11)$

Ketidakstabilan ini terlihat saat enkapsulat pigmen kubis merah ini dilarutkan ke dalam buffer dan diinkubasi selama 72 jam pada suhu $20^{\circ} \mathrm{C}$ kondisi gelap. Pada $\mathrm{pH}$ asam, perubahan $\Delta E$ tidak terlalu signifikan baik pada pewarna alami maupun pewarna sintetis (Ahmadiani et al., 2014). Enkapsulat pigmen kubis merah dapat diaplikasikan ke dalam produk pangan baik dalam bentuk $\mathrm{pH}$ asam maupun $\mathrm{pH}$ basa. Aplikasi pemberian warna merah dari enkapsulat pigmen kubis merah dapat diterapkan pada minuman fermentasi (yoghurt), minuman berkarbonasi, dan minuman berenergi, sedangkan pemberian warna biru dan hijau dapat diterapkan pada produk minuman instan. Aplikasi dari enkapsulat pigmen kubis merah ke dalam produk pangan bergantung dari komposisi produk pangan tersebut, metode pengemasan dan penyimpanan.

\section{Thermostabilitas warna}

Enkapsulat pigmen kubis merah mengalami degradasi setelah dipanaskan pada suhu $60^{\circ} \mathrm{C}$ selama 30 menit. Degradasi nilai $L^{*}$ menunjukkan nilai negatif pada $\mathrm{pH}$ 5-11 yang menunjukkan peningkatan kecerahan sebesar 0,6-15,2\% (Gambar $6 \mathrm{~A})$. Adanya perubahan suhu selama 30 menit memicu kerusakan yang lebih cepat dibandingkan pada suhu ruang, namun pada $\mathrm{pH}$ 2-4 warna merah pada enkapsulat pigmen kubis merah cenderung lebih stabil. Hal ini terlihat dari peningkatan warna merah pada $\mathrm{pH} 2$ sebesar $13,9 \%$, namun menunjukkan degradasi nilai $a^{*}$ yang lebih rendah dibandingkan $\mathrm{pH}$ basa pada $\mathrm{pH} 3$ dan $\mathrm{pH} 4$ sebesar $0,7 \%$ dan $0,4 \%$. Tingkat kemerahan (nilai $a^{*}$ ) juga mengalami degradasi selama perubahan suhu. Gambar 6B menunjukkan bahwa degradasi nilai $\mathrm{a}^{*}$ terbesar terlihat pada $\mathrm{pH} 5$ dan $\mathrm{pH} 6$ sebesar $121,2 \%$ dan 1065,9\%. 
Pada $\mathrm{pH}$ basa $(\mathrm{pH}$ 8-10) menunjukkan tingkat degradasi nilai $b^{*}$ yang linier dengan rentang 8,9$64 \%$ (Gambar $6 \mathrm{C}$ ). Nilai $b^{*}$ menunjukkan peningkatan derajat warna setelah pemanasan $60^{\circ} \mathrm{C}, 30$ menit dengan rentang 2,1-431,5\% pada $\mathrm{pH} 3-11$, namun pada $\mathrm{pH} 2$ pemanasan $60^{\circ} \mathrm{C}$ memberikan efek degradasi nilai $b^{*}$ sebesar $1,9 \%$.
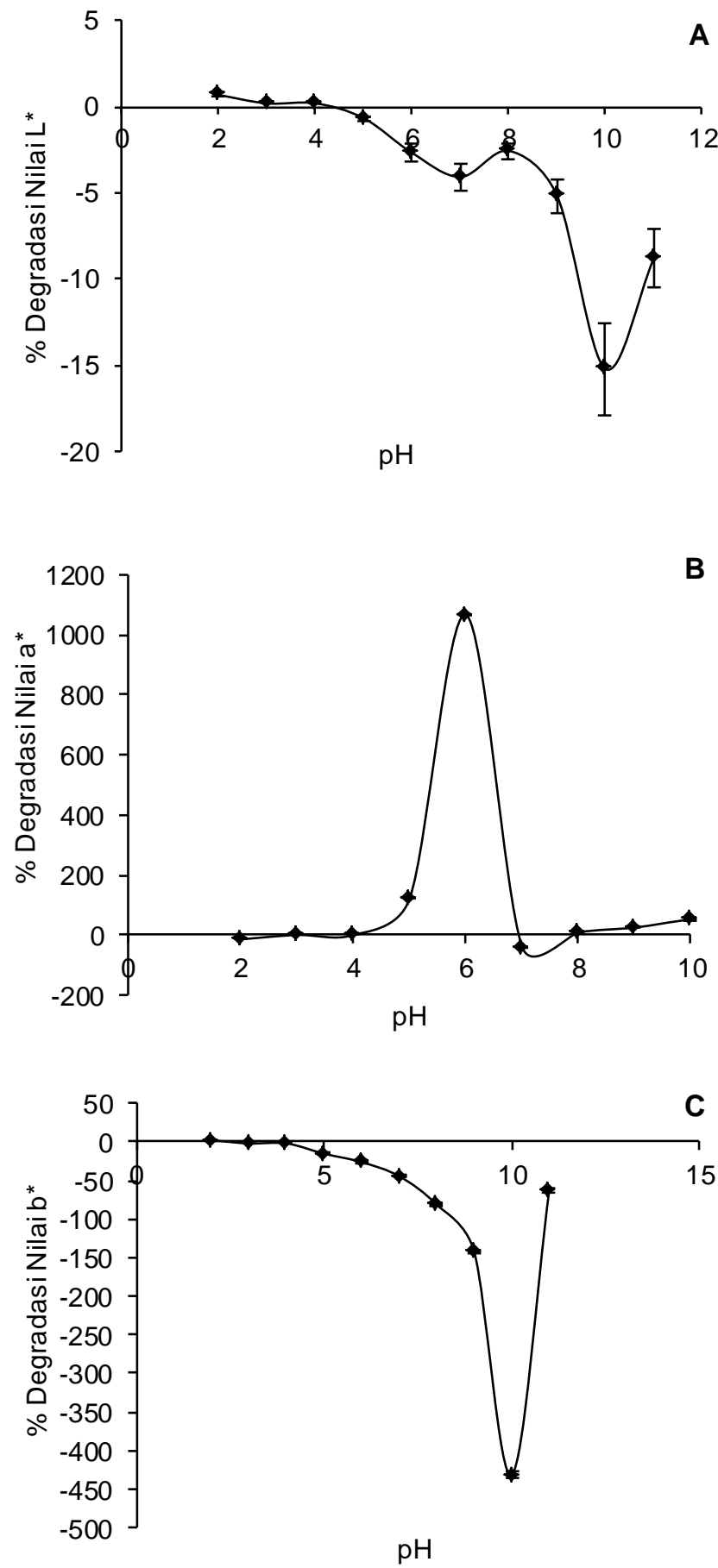

Gambar 6. Degradasi nilai $L^{*}$, $a^{*}$ dan $b^{*}$ pada uji thermostabilitas enkapsulat pigmen kubis merah suhu $60^{\circ} \mathrm{C}$ selama 30 menit dalam buffer Mclllvaine
Peningkatan nilai $\mathrm{b}^{*}$ tertinggi didapatkan pada $\mathrm{pH} 10$ sebesar $431,5 \%$. Kerusakan derajat warna enkapsulat pigmen kubis merah ditinjau dari segi nilai $L^{*}, a^{*}$, dan $b^{*}$ terjadi lebih cepat dibandingkan pada suhu $20^{\circ} \mathrm{C}$. Hal ini sesuai dengan penelitian Maatsch et al. (2016) yang menyatakan degradasi antosianin terjadi lebih cepat saat diinkubasi pada kondisi thermal $\left(80^{\circ} \mathrm{C}\right)$, kecuali pada bunga rosella yang cenderung lebih stabil dengan degradasi sebesar $15 \%$ selama 30 menit.

Tabel 1 menunjukkan perbedaan warna $(\Delta E)$ pada buffer Mclllvaine dengan rentang 2-11 setelah diinkubasi pada suhu $60^{\circ} \mathrm{C}$ selama 30 menit. Pada Tabel 1 terlihat bahwa tingkat perubahan warna paling jelas dimulai dari $\mathrm{pH} 6$ hingga $\mathrm{pH} 11$ dengan rentang $\Delta E$ sebesar 4,2-27,4. Pada $\mathrm{pH} 10$, menunjukkan perubahan warna yang cukup signifikan $(\Delta E$ 27,4), yakni dari warna biru kehijauan hingga menjadi warna kuning. Perubahan warna pada $\mathrm{pH} 2,4$, dan 5 hanya dapat dilihat oleh mata terlatih dengan nilai $\Delta E$ masing-masing sebesar 2,$7 ; 1,4$; dan 2,2, sedangkan $\mathrm{pH} 3$ perubahan warnanya tidak dapat terlihat oleh mata terlatih dengan $\Delta E$ sebesar 0,3 .

B Tabel 1. Perubahan nilai $\Delta E$ enkapsulat pigmen kubis merah pada suhu $60^{\circ} \mathrm{C}$ selama 30 menit dalam buffer Mclllvaine ( $\mathrm{pH}$ 2-11)

\begin{tabular}{cc}
\hline $\mathbf{p H}$ & $\boldsymbol{\Delta} \boldsymbol{E}$ \\
\hline 2 & $2,74 \pm 0,72$ \\
3 & $0,30 \pm 0,09$ \\
4 & $1,45 \pm 0,42$ \\
5 & $2,21 \pm 0,61$ \\
6 & $4,28 \pm 1,13$ \\
7 & $5,48 \pm 1,16$ \\
8 & $5,05 \pm 0,72$ \\
9 & $10,44 \pm 1,13$ \\
10 & $27,45 \pm 2,51$ \\
11 & $16,06 \pm 0,61$ \\
\hline
\end{tabular}

\section{Aktivitas antioksidan dan $\mathrm{IC}_{50}$}

Nilai $\mathrm{IC}_{50}$ enkapsulat pigmen kubis merah yang dilarutkan dalam metanol sebesar $725,65 \pm 0,09 \mathrm{ppm}$, sedangkan yang dilarutkan dalam air-metanol sebesar $258,25 \pm 0,10 \mathrm{ppm}$. Kubis merah yang dimaserasi menggunakan etanol-asam sitrat selama 3 hari kemudian dikeringkan dengan menggunakan freeze drying memiliki kadar $\mathrm{IC}_{50}$ sebesar 254,66 ppm (Senja et al., 2014). Kelarutan bahan dalam air lebih tinggi dibandingkan dalam metanol, sehingga kandungan bioaktif dalam kubis merah lebih banyak terekstrak dalam pelarut air-metanol. Hal ini ditunjukkan melalui data aktivitas antioksidan yang lebih tinggi pada pelarut air-metanol dibandingkan dengan menggunakan metanol murni. Adapun faktor yang memengaruhi kadar $\mathrm{IC}_{50}$ suatu bahan yakni kepolaran pelarut, kepolaran bahan yang akan diuji, kandungan bahan yang akan diuji, penggunaan bahan penyalut, dan metode ekstraksi bahan 
(Wahyuni dan Widjanarko, 2015; Putra et al., 2013). Kubis merah mengandung vitamin ( $A, B, C$, dan $E)$, mineral (K, Ca, $\mathrm{P}, \mathrm{Na}$, dan $\mathrm{Fe}$ ), sulfofaran, sianohidroksibutena, dan flavonoid (termasuk antosianin) yang dapat menunjang aktivitas antioksidan saat pengujian (Neelufar et al., 2012).

\section{KESIMPULAN}

Enkapsulat pigmen kubis merah menunjukkan warna merah pada $\mathrm{pH} 2-4$, warna ungu pucat mendekati transparan pada $\mathrm{pH} 5-7$, warna biru pada $\mathrm{pH}$ 8-10, dan warna hijau $\mathrm{pH} 11$ dengan aktivitas antioksidan sebesar $78 \pm 0,097 \%$ dan nilai $I_{50}$ sebesar 258,25 $\pm 0,10$ ppm. Ekstrak enkapsulat pigmen kubis merah memiliki kestabilan warna merah paling baik pada $\mathrm{pH}$ 2-3 dengan penyimpanan selama 72 jam dan suhu $20^{\circ} \mathrm{C}$, sedangkan pada $\mathrm{pH}$ basa ekstrak enkapsulat pigmen kubis merah cenderung terdegradasi $50 \%$ setelah disimpan selama 12 jam pada suhu $20^{\circ} \mathrm{C}$. Ekstrak enkapsulat pigmen kubis merah pada penyimpanan suhu $60^{\circ} \mathrm{C}$ selama 30 menit menunjukkan kestabilan pada $\mathrm{pH}$ 2-4 meskipun terjadi degradasi warna yang lebih cepat dibandingkan dengan penyimpanan suhu $20^{\circ} \mathrm{C}$.

\section{UCAPAN TERIMA KASIH}

Penelitian ini didanai oleh Kementrian Riset, Teknologi, dan Pendidikan Tinggi (Kemenristekdikti) melalui Program Insentif Riset Sistem Inovasi Nasional (SINAS) Nomor 272/SP2H/LT/DRPM/III/ 2016 tanggal 10 Maret 2016, dilanjutkan dengan Program Insinas Riset Pratama Individu (IRPI) tahun 2017 berdasarkan Surat Pengumuman tanggal 7 Maret 2017.

\section{DAFTAR PUSTAKA}

Ahmadiani N, Robbins RJ, Collins TM, Giusti MM. 2014. Anthocyanins contents, profiles, and color characteristic of red cabbage extracts from different cultivars and maturity stage. J Agr Food Chem 62: 7524-7531. DOI: 10.1021/ jf501991q.

Ahmadiani N, Robbins RJ, Collins TM, Giusti MM. 2016. Molar absorptivity $(\varepsilon)$ and spectral characteristics of cyanidin based anthocyanins from red cabbage. Food Chem 197: 900-906. DOI: 10.1016/j.foodchem.2015.11.032.

Asgar A, Musaddad D. 2006. Optimalisasi cara, suhu, dan lama blanshing sebelum pengeringan kubis. J Holtikultura 16: 349-355. DOI: 10.21082/jhort.v16n4.2006.p\%25p.
Bernstein A, Noreňa CPZ. 2015. Encapsulation of red cabbage (Brassica oleracea L. var. capitata L. f. rubra) anthocyanins by spray drying using different encapsulating agents. Braz Arch Biol Techn 58: 944-952. DOI: 10.1590/S1516-89132 015060226.

Chandrasekhar J, Madhusudhan MC, Raghavarao KSMS. 2012. Extraction of anthocyanin from red cabbage and purification using adsorption. Food Bioprod Process 90: 615-623. DOI: 10.1016/j.fbp.2012.07.004.

Dehbi F, Hasib A, Bouaziz M, Ouatmane A, Elbatal $H$, Jaouad A, Sayadi S. 2012. Effect of phenolic compounds and betalain pigments on the antioxidant capacity of moroccan prickly pear juices. J Agronomic Biol Sci 9: 2-7.

Dragichi GA, Alexandra LM, Breica BA, Nica D, Alda S, Liana A, Gogoasa I, Gergen I, Maria BD. 2013. Red cabbage, millennium's functional food. J Horti, Forestry, Biotechn 174: 52-55.

Gomathi P, Prameela R, Sanjeevakumar A. 2013. Antioxidant and free radical scavenging activity of anthocyanins from two forms of Brassica oleracea. Int J Pharm Clin Res 2: 1328-1332.

Habekost M. 2013. Which color differencing equation should be used?. International circular of graphic education and research 6: 20-32. https://www.hdm-stuttgart.de/international_circ le/circular/issues/13_01/ICJ_06_2013_02_069. pdf. [8 Desember 2016].

He F, Mu L, Yan GL, Liang NN, Pan QH, Wang J, Reeves MJ, Duan CQ. 2010. Biosynthesis of anthocyanins and their regulation in colored grapes. Molecules 15: 9057-9091. DOI: 10.33 90/molecules 15129057.

Hong Z, Meng Z. 2015. Microencapsulation of anthocyanins from red cabbage. Int Food Res Jl 22: 2327-2332.

Lopes TJ, Yaginuma SR, Quadri MGN, Quadri MB. 2011. Evaluation of red cabbage anthocyanins after partial purification on clay. Braz Arch Biol Techn 54(6): 1349-1356. DOI: 10.1590/S151689132011000600022.

Maatsch JM, Schweiggert RM, Carle R. 2016. Adulteration of anthocyanin- and betalainbased coloring foodstuff with the textile dye "reactive red 195" and its detection by spectrophotometric, chromatic, and HPLC-PDA-MS/MS analyses. Food Control 70: 333-338. DOI: 10.1016/j.foodcont.2016.06.012.

Molina GA, Martínez ARH, Valadez MC, Hernández FG, Estevez M. 2014. Effect of tetraethyl orthosilicate (TEOS) on the light and temperature stability of a pigment from Beta vulgaris and its potential food industry app- 
lication. Molecules 19: 17985-18002. DOI: 10.3390/molecules 191117985.

Neelufar S, Alekhya T, Sudhakar K. 2012. Pharmacognostical and phytochemical evaluation of Brassica oleracea Linn var. capitata forma rubra (the red cabbage). J Pharmaceut Biomed 2: $43-46$.

Putra SDR, Purwijantiningsih LME, Pranata FS. 2013. Kualitas minuman serbuk instan kulit buah manggis (Garcinia mangostana Linn.) dengan variasi maltodekstrin dan suhu pemanasan. http://e-journal.uajy.ac.id/4369/1/ JURNAL.pdf. [12 Oktober 2016].

Reyes LF, Zevallos LC. 2007. Degradation kinetics and colour of anthocyanins in aqueous extract of purple and red flesh potatoes (Solanum tuberosum L). Food Chem 100: 885-894. DOI: 10.1016/j.foodchem.2005.11.002.

Ribeiro LC, da Costa JMC, Afonso MRA. 2016. Hygroscopic behavior of lyophilized acerola pulp powder. Revista Brasileira de Engenharia Agríc ola e Ambiental 20: 269-274. DOl: 10.15 90/1807-1929/agriambi.v20n3p269-274.

Senja RY, Issusilaningtyas E, Nugroho AK, Setyowati EP. 2014. Perbandingan metode ekstraksi dan variasi pelarut terhadap rendemen dan aktivitas antioksidan ekstrak kubis ungu (Brassica oleracea L. var, capitata $f$. rubra). Trad Med J 19: 43-48.

Tanaka Y, Sasaki N, Ohmiya A. 2008. Biosynthesis of plants pigments: anthocyanins, betalains, and carotenoids. Plant J 54: 733-749. DOI: 10.1111/j.1365-313X.2008.03447.x.

Vargas FD, López OP. 2003. Natural Colorants for Food and Nutraceutical Uses. Chapter 8: Anthocyanins and Betalains. 167-220. CRC Press. Florida: USA.

Wahyuni DT, Widjanarko SB. 2015. Pengaruh jenis pelarut dan lama ekstraksi terhadap ekstrak karotenoid labu kuning dengan metode gelombang ultrasonik. J Pangan Agroind 3: 390-401.

Xavier MF, Lopes TJ, Quadri MGN, Quadri MB. 2008. Extraction of red cabbage anthocyanins: optimization of the operation condition of the column process. Braz Arch Biol Techn 51(1): 143-152. DOI: $10.1590 / S 1516-8913200800010$ 0018.

Yuliawaty ST, Susanto WH. 2014. Pengaruh lama pengeringan dan konsentrasi maltodekstrin terhadap karakteristik fisik, kimia, dan organoleptik minuman instan daun mengkudu (Morinda citrifolia L). J Pangan Agroind 3: 4152. 